\title{
Entrepreneurial Financing Based on (Dis)ability
}

\author{
Terry L. Howard, Gregory W. Ulferts \\ University of Detroit Mercy, Detroit, MI, USA \\ Email: howardtl@udmercy.edu, ulfertgw@udmercy.edu
}

How to cite this paper: Howard, T. L., \& Ulferts, G. W. (2020). Entrepreneurial Financing Based on (Dis)ability. Open Journal of Business and Management, 8, 2178-2194. https://doi.org/10.4236/ojbm.2020.85133

Received: July 2, 2020

Accepted: September 12, 2020

Published: September 15, 2020

Copyright $\odot 2020$ by author(s) and Scientific Research Publishing Inc. This work is licensed under the Creative Commons Attribution International License (CC BY 4.0).

http://creativecommons.org/licenses/by/4.0/ (c) (i) Open Access

\begin{abstract}
The purpose of this research was to add to a qualitative study by conducting a survey of entrepreneurs to gain an understanding of the financing options used by small businesses. The results of an initial qualitative case study of three entrepreneurs suggested that financing issues were of concern to entrepreneurs with disabilities (EWDs). The quantitative analysis determined whether differences existed in the use of funding between EWDs and entrepreneurs without disabilities (EWODs). Overall, the sample size of 251 allowed the researcher to determine normal distribution and that the results were reliable. The independent sample t-tests resulted in the rejection of both null hypotheses, indicating that significant differences existed in the use of the studied financing options. There is a statistical difference between EWDs and EWODs relative to the receipt of financing (traditional and alternative).
\end{abstract}

\section{Keywords}

Entrepreneur, Disability, Financing, Small Business, Ownership

\section{Introduction}

\subsection{Background}

Self-employment enables entrepreneurs with disabilities (EWD) to gain the opportunity to adapt their work to their needs, achieve flexibility and accommodation, which are the usual barriers to employment. Beyond general employment assistance, there is little public program support to assist EWDs in self-employment (Renko, Parker Harris, \& Caldwell, 2016). The Department of Education's Rehabilitation Services Administration funded programs to prepare people with disabilities for employment; yet, in 2012, self-employment 
accounted only for $2.4 \%$ of the case closures (Drake, Bond, Goldman, Hogan, \& Karakus, 2016).

Tasavori, Ghauri, and Zaefarian (2016) studied social entrepreneurship in India, finding that various factors contributed to social enterprise success. First, success consisted of environmental factors such as product or service demand and the political arena's expectations. Second, other factors involved marketing strategies and specific organizational characteristics, including support from management and adequate financial assistance. Third, success consisted of focused entrepreneurial discipline. Tasavori et al. concluded that these issues were critical predictors of success, with financing being the most significant issue. Also, while many social entrepreneurs have sufficient private funding to start their enterprises, investment in such organizations rose (Ahaibwe \& Kasirye, 2015; Kickul \& Lyons, 2015; Tarilaye \& Okoye, 2017).

\subsection{Research Problem and Significance}

Given the narrow scope of the studies on entrepreneur characteristics conducted by Antoncic, Bratkovic Kregar, Singh, and DeNoble (2015) and Rodríguez-Gutiérrez, Moreno, and Tejada (2015), the research conducted by Walter and Heinrichs (2015) provided a comprehensive understanding of the study conducted over 30 years. Walter and Heinrichs explored the relationship between personal characteristics and entrepreneurial options. The goal was to comprehend six perspectives (trait, cognitive aspects, affective attributes, goals, education, and economic issues) and how these perspectives lead an individual to become an entrepreneur. Howard (2017) found that successful EWDs' decision-making choices depended on a high level of market and product knowledge, the formation of marketing and financial relationships, and adherence to cost-based management of operational resources. Former studies on the decision to start a company primarily focused on the trait and financial matters. Van Gelderen, Kautonen, and Fink (2015) explored the concept that an entrepreneur takes action despite uncertainty and incomplete knowledge of the present.

In addition to the factors inspiring individuals to become entrepreneurs, other factors existed that prevented making decisions. One of those was the fear factor. Cacciotti and Hayton (2015) assessed the literature on the impact of fear in the decisions to start new enterprises. Cacciotti and Hayton investigated the issue from a different perspective than commonly used they looked at the fear of failure and how it influences the decision to establish a new business. However, another effect pertains to fear as a function of individual personality rather than as a temporary barrier to an enterprise's initiation. Cacciotti and Hayton identified a failing in current research, which primarily focused on the fear of having a new business fail based on the personal and financial costs of business failure.

Renko et al. (2016) found that the ratio for those with disabilities is 1:10; 
however, there is little literature regarding the contributions of this population, which is surprising due to the tendency of this population to be self-employed. There is also a limited understanding of the barriers faced by this population in their self-employment, including lack of business knowledge and training, lack of organizational support and advice beyond the first year, lack of information on how entrepreneurship affects their disability benefits and policies, and, most importantly, a lack of access to financing (Hsu, 2016).

\subsection{Research Questions and Hypotheses}

The quantitative research questions and their associated hypotheses for this aspect of the mixed-methods study are:

RQ1: What strategies are used by EWD, and what barriers to financing, regardless of type (traditional or alternative), are faced, as compared to EWOD?

RQ2: Is there a difference in EWDs and EWODs in the receipt of traditional financing?

$\mathrm{H} 20$ : There is no statistically significant difference in EWDs and EWODs in the receipt of traditional financing.

$\mathrm{H} 21$ : There is a statistically significant difference in EWDs and EWODs in the receipt of traditional financing.

RQ3: Is there a difference in EWDs and EWODs in the receipt of alternative financing?

H30: There is no statistically significant difference in EWDs and EWODs in the receipt of alternative financing.

H31: There is a statistically significant difference in EWDs and EWODs in the receipt of alternative financing.

This study builds on the original study by Howard (2017) and consists of four parts: the literature review will contain information regarding entrepreneurship and financing; the research methodology will provide information regarding the completion of the study; the findings and analysis will contain the outcome of the research, and; the conclusions will include a discussion of the results.

\section{Literature Review}

\subsection{Influences to Entrepreneurship}

The literature review by Howard (2017) discussed in this section identified research on both disability and entrepreneurship. Tipu (2016) developed a conceptual framework that provided a sound basis for this investigation, the model of necessity-driven entrepreneurship. Tipu compared the behaviors of necessity-driven entrepreneurs (NDEs) and opportunity-driven entrepreneurs (ODEs). Using a case study approach, Tipu identified differences in these two types of entrepreneurs during their companies' start-up phases and their overall perspec- 
tives toward their businesses. Tipu developed a framework based on how the two categories of entrepreneurs thought, or entrepreneurial cognition about the critical success factors of start-up companies (i.e., planning, risk management, networking, financial management), which influenced what these individuals did to start their businesses or their entrepreneurial action. Tipu found that entrepreneurial cognition affected business activities in this framework. Tipu also defined ODEs as driven by the need for achievement, freedom, or independence. At the same time, NDEs were self-employed as a last resort to survive when different employment opportunities were not available. Using a multiple case approach of four entrepreneurs, two identified as ODEs and two as NDEs, Tipu used various surveys, interviews, and other data collection on entrepreneurs whose businesses had survived for at least three years. Tipu found that many of the behavioral patterns of NDEs and ODEs were similar, with none preparing a business plan or going for external financing. They all had realistic assessments of their skills and available resources. However, Tipu also found that ODEs relied on availability heuristics during start-upstart-ups, relied heavily on readily available information and conducting counterfactual thinking, and tried to learn from past mistakes and failures. In contrast, NDEs tended not to imagine anything except actual outcomes and were more tightly bound to a realistic assessment of circumstances without believing anything other than what was real. For NDEs, entrepreneurship was a desperation move rather than a free choice, and this influenced their behaviors toward their companies (Tipu, 2016). In a qualitative study, Howard (2017) found that entrepreneur characteristics included passion, values, support, dedication, and background, while managerial characteristics included market and product knowledge, marketing and financial relationships, operational ability, and leadership. Howard, Peterson, \& Ulferts (2017) noted the challenges created by the changing labor market, the consumer base, and the competition, representing both challenges and opportunities.

Freeland and Keister (2016) investigated how race and ethnicity affected the persistence of new ventures after two years, exploring the African American population as opposed to the Hispanic community. Freeland and Keister hypothesized that African Americans have less access to formal credit sources than either White or Latino entrepreneurs and that they invested more of their funds in their ventures. Freeland and Keister found that African Americans indeed had only $20 \%$ of the likelihood of getting credit from an outside source as Whites or Hispanics. According to Freeland and Keister, the reasons for this varied, including the reduced social capital in the high-poverty, racially segregated inner-city neighborhoods and the fact that African Americans were only half as likely as Hispanics to be able to get funding from local area firms. Also, while Hispanic suppliers often are expected to offer credit to Hispanic entrepreneurs, no such relationship existed for African American vendors and African American-owned businesses. Overall, Freeland and Keister found that race 
and ethnicity were not significant in the determination to create a new company. For start-ups that did not achieve success after two years, African Americans were more likely to persist while Hispanics were more likely to drop the business (Freeland \& Keister, 2016; Ortiz-Walters, Gavino, \& Williams, 2015).

Jensen (2015) conducted surveys of entrepreneurs in North Dakota at start-up and again five years later to determine the types of challenges faced in building a small business. Not all the companies survived the full five years, and Jensen analyzed the data collected to determine characteristics that differed between those that survived and those that did not. Furthermore, Jensen identified differences in problems during the start-up period and five years of operation. Like Ponzio, Brichetto, Zaratin, Battaglia (2015), Jensen did not explore concerns associated with the loss of benefits during the start-up period. Overall, Jensen found that regulations and taxes were more of an issue in later stages and less so in the early stages. The most significant tax burden was in property taxes, especially for those with substantial growth. Critical issues for survivor companies were licensing problems, while start-ups faced more difficulties in financing.

\subsection{Access to Funding}

The availability of funds influenced the success or failure of new enterprises. Bewaji, Yang, and Han (2015) probed whether minority entrepreneurs obtained institutional funding to establish their businesses to the same degree as non-minority entrepreneurs. In earlier research, Bewaji et al. found that minority entrepreneurs tended to be from lower- or middle-class family backgrounds were younger, more likely married, and often entrepreneurially experienced. Also, minority entrepreneurs managed to have college degrees with primary motivators of job satisfaction and a desire for achievement. Despite these factors, which indicated inherent success, previous research found that minority entrepreneurs had a higher failure rate than non-minority entrepreneurs. Bewaji et al. hypothesized that an older, educated minority entrepreneur with prior experience in industry and entrepreneurship was more likely to receive funding from known financial institutions than other minority applicants. The youth had a marginally negative impact on access to financing, but education and antecedent experience in the industry determined markers for funding access (Bewaji et al., 2015). The primary constraints included minority status, lack of industry experience, and lack of education, with minority status being the single most significant factor.

\subsection{Fresh Funding Sources}

New sources of funding affected the ability of entrepreneurs with disabilities to get needed resources for their enterprises. Crowdfunding was one of the innovations in financing start-up companies. Some entrepreneurs were highly resistant to taking advantage of this source of funding. Using impression management, 
Gleasure (2015) suggested that individuals present themselves in service to goals and encouragement of esteem from others. In doing interviews with participants, Gleasure found three principal themes developed. First, some entrepreneurs believed that crowdfunding offered little strategic value to their business because they ran business-to-business (B2B) businesses or felt they had a niche market. Second, some entrepreneurs expressed passive acceptance of crowdfunding but a refusal to take impelling steps to achieve such funding. A third theme included that some small business owners felt they needed time and resources to investigate this financing option. For entrepreneurs such as EWDs, who encounter high obstacles to receiving significant external financing, the use of crowdfunding may be an underutilized source (Cacciotti \& Hayton, 2015; Gleasure, 2015; Xu, Zheng, Xu, \& Wang, 2016).

\subsection{Barriers to Funding}

For entrepreneurs such as entrepreneurs with disabilities, who experienced high barriers to receiving significant outside financing, the use of crowdfunding was an underutilized resource. While most of the research on crowdfunding focused on strategies for raising sufficient money to start a business or a project, $\mathrm{Xu}$ et al. (2016) explored the satisfaction of sponsors in crowdfunded financing of new enterprises to understand how best to maximize that satisfaction. Noting that most crowdfunding research focused on improving the amount of money achieved through this avenue, $\mathrm{Xu}$ et al. focused on what attributes of the start-up maximized the funders' satisfaction with their decision to give money to this organization. Xu et al. found that keys to that satisfaction included timely delivery, product quality, project novelty, sponsor participation, and entrepreneur activeness.

\section{Research Methodology}

This mixed-methods study aimed to explore the strategies used for and barriers to financing faced by EWDs. This study's findings can help EWD leaders develop strategies for increasing profitability, benefiting their employees, families, and communities. These leaders can create a social change from dependency to independence through successful self-employment. The purpose of the discussion in this section is to outline the continuing study.

\subsection{Research Design}

A multiple case study approach required completing in-depth analyses of participants (Dasgupta, 2015; Lewis, 2015; Rule \& John, 2015; Wilson, 2016). The Howard (2017) qualitative research consisted of a case study approach using various data sources, including interviews of the entrepreneurs with disabilities, interviews with sources of funding, business financial information, interviews with business advisors or mentors, community agencies, and direct observation of how the company operates. By implementing various data collec- 
tion techniques, the researcher was able to develop a comprehensive understanding of the strategies used to achieve business profitability while simultaneously providing methodological triangulation for data analysis, ensuring saturation of information for each of the three different EWDs for the qualitative study.

To compare EWDs and EWODs, a survey was developed to collect data with input from subject-matter experts.

\subsection{Population and Sampling}

The qualitative study population consisted of Michigan EWDs, which had profitable operations for at least three years in the past or present (Howard, 2017). Following the research suggestions of Dasgupta (2015), Lewis (2015), Rule and John (2015), and Wilson (2016), participant recruitment involved employing a convenience approach through a local organization that supports people with disabilities and other business groups in the community. The intent was to determine potential participants by recruiting through local business support groups. Using a partial snowball effect, participants helped in referring to other potential members. Participants did not receive any financial aid or other incentives. There was appropriate care to ensure that the participants had the necessary information to decide if they wanted to participate. Specific procedures assured members of the protection of their privacy, identity, and similar ethical issues.

The quantitative portion of the study involved a non-random sample determines the data relationships. The questionnaire was distributed electronically. Using $G^{\star}$ Power software, a minimum sample size of 220 respondents was determined to be sufficient to test the research questions.

\subsection{Data Collection}

\subsubsection{Qualitative}

In the qualitative study by Howard (2017), the interview questions included the following:

1. "What were the critical success factors that you used to develop your strategies?

2. What barriers did you encounter in implementing your strategic plans?

3. How did you address the obstacles to achieving profitability?

4. What concrete steps did you take to measure the effectiveness of your strategies for achieving profitability?

5. What changes in plans occurred over the operating life of your business?

6. What additional information would you like to add beyond that asked in the previous questions?"

These questions sought to understand, the strategies used by successful entrepreneurs with disabilities. All interviews conducted with the participants were audio-recorded with no one else hearing and transcribing that data, assigning a 
numerical value to each interview and tape. Transcriptions occurred within 72 hours of each meeting. Once transcribed, member checks occurred. In this process, the participant reviewed the transcribed interview in its analyzed form. As recommended in the research by Resnick (2015); Simpson and Quigley (2016), interviewees examined the information to confirm the accuracy and verify that the underlying message that he or she was attempting to get across was still present within the interview text and analyzed data. The researcher noted any qualifications or adjustments needed. Once the participants confirmed that the information was accurate, removal of the names from the members' records occurred for confidentiality purposes, replacing them with pseudonyms. Direct observations occurred at predetermined days and times and with the agreement of the researcher and the participant. The views lasted for at least two weeks at each location, and setup based on the best schedule for the member, recording the implementation of strategies discussed, and those not mentioned during the interview process.

\subsubsection{Quantitative}

The data collection was done through emails from the small business database and entered into the software for summary and tabulation. Participants were notified that their participation was confidential and only for use in the research project. The survey encompassed small business owners included in the database for Michigan.

\subsection{Data Analysis}

\subsubsection{Qualitative}

The analysis process used in this study followed the suggestions from Dasgupta (2015), Lewis (2015), Nelson, London, \& Stroble (2015), Rule and John (2015), and Wilson (2016). A researcher's understanding of a problem increases by triangulating multiple sources and methods (Shabani Varaki, Floden, \& Kalatehjafarabadi, 2015). The review of the interview transcripts, notes from observations, and other relevant documents, resulted in the development of initial categories, themes, and relationships. Through an iterative process, different coding and analysis levels occurred, leading to the identification of the main themes. Maintaining consistency with the research question and the conceptual framework was essential. After undertaking these steps, the researcher considered the data in determining the universals of the various interviews and other collected data to present an overall set of conclusions. Finally, where possible, these findings were tested and formulated into recommendations that could guide programs and services directed at the EWD population.

\subsubsection{Quantitative}

Disability was the independent variable in this quantitative study. The data compared financing methods (traditional or alternate) using a t-test for determining if significant difference exists between EWDs and EWODs. The study 
used a t-test to test the hypotheses.

\section{Findings and Analysis}

\subsection{Demographic Summary}

Over half of the 251 small business owners or 131 (52.2\%) were Caucasians, 73 (29.1\%) were African American, 18 (7.2\%) were Asian, 19 (7.6\%) were Hispanic, and 10 were other (3.9\%). Among these 251 small business owners, 120 (47.8\%) were EWODs, and 131 (52.2\%) were EWDs. Regarding the socio-economic class of the business location of the 251 small business owners, almost half or 125 $(49.8 \%)$ of the business location were in middle lower and upper level, 71 (28.3\%) were in the upper level, 55 (21.9\%) were in lower level. A majority or 207 (82.5\%) out of the 251 small business owners were operating for at least five years, verifying the operational stability of the respondents. Of the 251 respondents, there were 151 males (60.2\%) and 100 female (39.8\%) small business owners. Finally, 43 (17.1\%) out of the 251 respondents were under the age of 35 , 35 to 44 years old numbered 133 (53.0\%), 45 to 60 years old numbered 35 (13.9\%), and aged over 60 years old numbered 40 (15.9\%). The data shows that the firms were operationally stable (Tables 1-3).

Table 1. Ethnicity.

\begin{tabular}{ccc}
\hline Ethnicity & Frequency & Percentage \\
\hline African American & 73 & 29.1 \\
Asian & 18 & 7.2 \\
Caucasian & 131 & 52.2 \\
Hispanic & 19 & 7.6 \\
Other & 10 & 3.9 \\
Total & 251 & 100 \\
\hline
\end{tabular}

Table 2. Age.

\begin{tabular}{ccc}
\hline Age & Frequency & Percentage \\
\hline Under 35 & 43 & 17.1 \\
$35-44$ & 133 & 53.1 \\
$45-60$ & 35 & 13.9 \\
Over 60 & 40 & 15.9 \\
Total & 251 & 100
\end{tabular}

Table 3. Disability.

\begin{tabular}{ccc}
\hline Status & Frequency & Percentage \\
\hline EWD & 131 & 52.2 \\
EWOD & 120 & 47.8 \\
Total & 251 & 100 \\
\hline
\end{tabular}




\subsection{Entrepreneurship Financing and Barriers}

Table 4 summarized the data on the use of the two financing options. These statistics showed how many small business owners received financing for their business. The frequency and percentages revealed that the majority of 197 (78.5\%) out of the 251 small business owners used traditional funding, while 105 $(41.8 \%)$ used funds from family, friends, or community organizations.

The participants in this study had confidence in self, determination, perseverance, leadership, and were results-oriented. Within this study, participants enjoyed support from family and friends in the development of businesses, leading to an increased capacity to gather resources and resolve problems. Personal values, passion for the firm, and a positive attitude about abilities were essential for the success of the organization and the well-being of the participant. Therefore, there were different influences on the decision for the participant to establish a business. However, these individuals' characteristics varied due to their demographics, which also affected internal motivation. Tipu (2016) identified differences in the behaviors between necessity-driven entrepreneurs and opportunity-driven entrepreneurs during the start-up phases of their companies and their overall perspectives toward their businesses.

This study's qualitative results validated the differences between one participant motivated to become an entrepreneur due to prior experience with an employer, and two members are driven by necessity. Based on the participants' evidence, it was noted that there were different experiences by each and often based on the differences in entrepreneurship education. Of particular importance in this model was that entrepreneurs with disabilities were more likely to start a business but less liable to sustain it for extended periods. This result often attributed to a lack of understanding of the long-term requirements of sustainability, lack of funding, lack of support, and lack of education. Therefore, it is essential for entrepreneurs of all types, but especially those with disabilities, have additional support systems designed to assist them with their specific needs.

On the other hand, many of these systems are ineffective for the needs of entrepreneurs with disabilities because they cannot meet all requirements, including capital provision. Renko et al. (2016) identified key variables, including start-up capital, and training or education tailored for the entrepreneur with disabilities. For Participant 3, the training programs added support to developing the entrepreneur with disabilities' talent and future business. In all cases, the companies emerged from limited start-up capital. The prelaunch phase included finding opportunities, evaluating them, collecting resources needed, and doing

Table 4. Types of financing.

\begin{tabular}{ccc}
\hline Type of Financing & Frequency & Percent \\
\hline Traditional (bank loan, revolving credit, trade credit) & 197 & 78.5 \\
Alternative (family/friends, community organizations) & 105 & 41.9 \\
\hline
\end{tabular}


research. In all cases, similar prelaunch activities occurred. The launch phase involved setting up the legal entity, protecting intellectual property, and developing a business model. Participant 1 and 2 created legal entities, while Participant 3 copyrighted materials. The post-launch phase included building a customer base, hiring key employees, negotiating, and improving product design. These activities required experience and knowledge. The active involvement of mentors offset the lack of expertise by Participants 2 and 3 . The key factors identified as contributing to entrepreneurial success and competitiveness were the features of the individual, elements of the enterprise, and the business's managerial attributes; all were significant in determining the business success (Rodríguez-Gutiérrez et al., 2015). Personal characteristics of the entrepreneur were an essential factor in the success or failure of a start-up. All three participants displayed personal characteristics that contributed to their accomplishments.

Matthew Scott et al. (2014) found that family support was essential to entrepreneurs, especially for women and especially those women in cultures, considering men as being superior. Of particular note in this study, however, was the importance of all three participants having mentors available who assisted the entrepreneurs with disabilities to develop business skills and offering key contacts and support to overcome barriers. The barriers included lack of business knowledge and training, lack of organizational support and advice beyond the first year, lack of information on how entrepreneurship affected their disability benefits and policies, and, most importantly, a lack of access to financing (Hsu, 2016). These barriers were significant because they impact the sustainability of the business in the long-term and impact the entrepreneur's short-term ability to establish decisive business operations. Howard, Ulferts, \& Hannon, (2019) noted small business owners need to recognize the importance of innovative technologies plus other innovations as critical components of maintaining a relevant business.

According to Participant 1, "One thing I learned very early, or maybe back when I was a kid when you want something you need to save for it ... You put money in the bank, and you save because someday you're going to need it for something that you want. When you have your own business, I believe that every cent should go back into the business ... I had my business checking account and paid for things like that, all of my equipment, out of my business account. Did that way for almost 10 years. About eight years at this point that I would have been doing it this way, basically working out of my home. My office was in my home ... Like I said, I never talked to anybody at a bank, I never needed a loan or anything like that." Participant 2 stated, "You can't get a loan from the banks ... I tried. I had the banks out ... And you'd be begging, they'd want printouts and this and that, and that and this. Your accounts, you know, they wanted everything but the sun. And being small, you just can't get it, otherwise you got to put up collateral. Your first, last, middle born, your house. It's not that easy ... 
I have a line of credit now with the bank and the only reason why I have a line of credit ... It's funny, with all these years of being self-employed, the more money you have, the more they're willing to give you without strings attached. So, the more money you have, it's easier to get money. I've learned that over my time being in business ... And the banks see that and, boy, they were all over me, like glue. That's why they wrote me a note to buy this building with no questions asked. Gave me a line of credit, no questions asked."

\subsection{Significance in Financing}

The t-tests were used to determine whether significant differences existed between EWDs and EWODs use of financing (traditional or alternative). The t-tests showed that differences existed in the use of financing (traditional or alternative) between those EWDs and EWODs. The Levine's test for variance equality showed that the variances in the use of traditional financing $(\mathrm{F}=9.81, \mathrm{p}$ $=0.01)$ and alternative financing $(\mathrm{F}=12.13, \mathrm{p}<0.001)$ were not equal across the two groups of EWDs and EWODs with p-values less than 0.05 .

Analysis of the $t$-tests identified that the use of traditional financing ( $t$ $(209.53)=4.31 ; \mathrm{p}=0.04)$ and alternate financing $(\mathrm{t}(231.31)=6.77 ; \mathrm{p}=0.02)$ were statistically significantly different between the two population groups of EWDs and EWODs with p-values greater than 0.05 . The results showed a statistically significant difference between EWDs and EWODs relative to the receipt of traditional financing. There is a statistically significant difference between EWDs and EWODs relative to alternate funding.

Reddington and Fitzsimons (2013) interviewed EWDs in micro enterprises, organizations with less than ten workers and different levels of wages. Using a mixed-method approach, Reddington and Fitzsimons used a unique approach rather than a strictly qualitative one as done in many other papers. Reddington and Fitzsimons brought together surveys and interviews with various entrepreneurs and bankers to ascertain accessibility to funding. Reddington and Fitzsimons identified that one critical element to entrepreneurial success came from a blend of family support. The results of this study showed the same critical factor. Socioeconomic aspects included a variety of unique issues, including contacts and networks, relationships, support from family, support from community agencies, accessibility of capital, and other impediments to EWDs. The need for assistance from peers, banks, and government agencies or other sources of funding was one of the most underlying issues for EWDs (Reddington \& Fitzsimons, 2013).

\section{Conclusion}

Because there are limited research studies on EWDs, the findings of this study provide additional perspective on previous research. Previous research has identified a capital accessibility between EWDs and EWODs because of differences in the availability of financing methods. The results indicate that EWDs and 
EWODs experience different usage rates of various financing options available to them. Therefore, the research results support most prior research studies showing that entrepreneurs struggle on financing by traditional methods while identifying that EWDs do not have equal access to financing as EWODs.

In the qualitative study, there was evidence that individuals with disabilities expressed examples of discrimination (Howard, 2017). In some cases, the EWDs expressed perceived attitudes by people who deem people with disabilities as "less than" or "inferior" for varying reasons. In other settings, these individuals are considered incapable because of their disability. For example, it is commonplace for people without disabilities to pass judgment on persons with disabilities as lacking intelligence. However, many people with disabilities are highly knowledgeable, possibly showing more intelligence than those without disabilities. Many EWDs and other people with disabilities have a propensity to accommodate their disability. This tenacity to maintain a normal life demonstrates a broad range of innovations. Persons with disabilities see going to work as a part of life, a foundation of identity, self-esteem, and economic assistance (Saunders \& Nedelec, 2014; Howard, 2017). Self-employment through small business ownership provides a needed identity. EWDs can be successful. Access to traditional forms of financing may be hindered by attitudes and perceptions other than the business itself.

Koubâa (2014) examined the role of microfinance in the success of entrepreneurs. Koubâa concentrated on informal financing (i.e., friends and family) and on microfinance financing for start-ups to see how human capital establishes access to financing for entrepreneurs with restricted access to other types of investment. This result is especially applicable to disadvantaged entrepreneurs, including women, who often have less accessibility to formal financing alternatives. Koubâa found that determining factors for receiving financing included at least some degree of education, experience or age (older business individuals preferred over younger ones), and parental or family business experience. Alternative financing was the only resource for younger entrepreneurs, particularly had access to initial capital of their own and certain degree of business experience. According to the findings, there is a statistical difference between EWDs and EWODs. To support previous research, EWDs have lower usage rates because of their inability to gain access to financing based on the obstacles they face. The alternative financing section of the survey instrument showed a large number of respondents received financing from their family and other close relationships.

Another possible source of funding is micro-financing operations. In emerging countries, such financing usually bypass traditional banking and venture capital processes. Weber and Ahmad (2014) explored micro-financing options for women entrepreneurs in Pakistan. Weber and Ahmad wanted to determine if microfinance provided female entrepreneurs in Pakistan with a method to im- 
prove their financial condition, despite the cultural obstacles they face in establishing a business. Females in Pakistan have limited availability of bank financing and must depend micro financing and other alternative financing. In this regard, the women were like many (but not all) EWDs in the United States. Weber and Ahmad studied whether other issues (age, marital status, country vs. urban, etc.) affected the impact that microfinancing had on the women's equality level, and how micro financing enhanced the situation if it did. Weber and Ahmad found that women who had loan cycles in micro financing were more successful than those who were only beginning an investment cycle. The basic difference appeared in subsequent periods because the borrower could determine the use of the credit, demonstrating a vital sign of empowerment over financing. Finally, Weber and Ahmad decided that micro financing provided significantly to fiscal empowerment.

Alternative financing through family, friends, community organizations, cooperative funding provides a direct transaction between borrowers and lenders while avoiding many of the barriers of traditional lending institutions. Past literature focuses on entrepreneurs' problems in gaining traditional financing, which suggests that EWDs have similar issues in finding alternative financing options. Alternative financing is easier to find, but the results demonstrate a significant difference between EWDs and EWODS. Most entrepreneurs are not employing this financing mechanism. The low usage by all entrepreneurs suggests that alternative financing is an unexplored alternative by both EWDs and EWODs.

Fresh sources of financing may affect the ability of EWDs to get needed resources for their businesses. Crowdfunding is one of the innovations in funding start-up and developing companies. Some entrepreneurs are extremely opposed to taking advantage of this resource for financing. Using impression management, Gleasure (2015) found three principal themes. First, some entrepreneurs felt that crowdfunding offered little strategic value to their small business. Second, some entrepreneurs conveyed some acceptance of crowdfunding but a refusal to achieve such financing. A third theme included that some small business owners felt they needed time and resources to investigate this financing option. For entrepreneurs such as EWDs, who encounter high obstacles to receiving significant external financing, the use of crowdfunding may be an underutilized source.

The results indicate that EWDs and EWODs experience different rates of use of financing options. Therefore, the research does support prior research that EWDs do not have equal access to financing as EWODs. There are barriers that impact EWDs. While both EWDs and EWODs use alternative financing, there is a significant difference between EWDs and EWODS. These results confirm the qualitative research conducted. EWDs do not have equal access to financing and alternative financing. 


\section{Conflicts of Interest}

The authors declare no conflicts of interest regarding the publication of this paper.

\section{References}

Ahaibwe, G., \& Kasirye, I. (2015). Creating Youth Employment through Entrepreneurship Financing: The Uganda Youth Venture Capital Fund. Economic Policy Research Centre (EPRC).

Antoncic, B., Bratkovic Kregar, T., Singh, G., \& DeNoble, A. F. (2015). The Big Five Personality-Entrepreneurship Relationship: Evidence from Slovenia. Journal of Small Business Management, 53, 819-841. https://doi.org/10.1111/jsbm.12089

Bewaji, T., Yang, Q., \& Han, Y. (2015). Funding Accessibility for Minority Entrepreneurs: An Empirical Analysis. Journal of Small Business and Enterprise Development, 22, 716-733. https://doi.org/10.1108/JSBED-08-2012-0099

Cacciotti, G., \& Hayton, J. C. (2015). Fear and Entrepreneurship: A Review and Research Agenda. International Journal of Management Reviews, 17, 165-190.

https://doi.org/10.1111/ijmr.12052

Dasgupta, M. (2015). Exploring the Relevance of Case Study Research. Vision: The Journal of Business Perspective, 19, 147-160. https://doi.org/10.1177/0972262915575661

Drake, R. E., Bond, G. R., Goldman, H. H., Hogan, M. F., \& Karakus, M. (2016). Individual Placement and Support Services Boost Employment for People with Serious Mental Illnesses, But Funding Is Lacking. Health Affairs, 35, 1098-1105.

https://doi.org/10.1377/hlthaff.2016.0001

Freeland, R. E., \& Keister, L. A. (2016). How Does Race and Ethnicity Affect Persistence in Immature Ventures? Journal of Small Business Management, 54, 210-228.

https://doi.org/10.1111/jsbm.12138

Gleasure, R. (2015). Resistance to Crowdfunding among Entrepreneurs: An Impression Management Perspective. The Journal of Strategic Information Systems, 24, 219-233. https://doi.org/10.1016/j.jsis.2015.09.001

Howard, T. (2017). Strategies for Entrepreneurs with Disabilities to Sustain a Successful Small Business. Walden Dissertations and Doctoral Study Collection.

https://scholarworks.waldenu.edu

Howard, T., Peterson, E., \& Ulferts, G. (2017). A Note on the Value of Diversity in Organizations. International Journal of Management and Decision Making, 16, 187-195. https://doi.org/10.1504/IJMDM.2017.085629

Howard, T., Ulferts, G., \& Hannon, J. (2019). Leadership Styles of Small Business Owners: Linking Theory to Application. Journal of Leadership, Accountability and Ethics, 16, 47-55. https://doi.org/10.33423/jlae.v16i2.2021

Hsu, C.-C. (2016). Social Entrepreneurship for People with Disabilities: Barriers and Facilitators to Business Start-Up. UIC.

Jensen, J. L. (2015). An Examination of the Burdens Faced by Entrepreneurs at Start-Up and Five Years Later. Journal of Entrepreneurship and Public Policy, 4, 152-170. https://doi.org/10.1108/JEPP-07-2014-0028

Kickul, J., \& Lyons, T. S. (2015). Financing Social Enterprises. Entrepreneurship Research Journal, 5, 83-85. https://doi.org/10.1515/erj-2015-0006

Koubâa, H. F. (2014). Start-Up Informal Finance and Formal Microfinance: The Role of 
Human Capital. Strategic Change: Briefings in Entrepreneurial Finance, 23, 415-423. https://doi.org/10.1002/jsc.1986

Lewis, S. (2015). Qualitative Inquiry and Research Design: Choosing among Five Approaches. Health Promotion Practice, 16, 473-475. https://doi.org/10.1177/1524839915580941

Matthew Scott, J., T., Harrison, R., Hussain, J., \& Millman, C. (2014). The Role of Guanxi Networks in the Performance of Women-Led Firms in China. International Journal of Gender and Entrepreneurship, 6, 68-82. https://doi.org/10.1108/IJGE-03-2013-0014

Nelson, I. A., London, R. A., \& Strobel, K. R. (2015). Reinventing the Role of the University Researcher. Educational Researcher, 44, 17-26. https://doi.org/10.3102/0013189X15570387

Ortiz-Walters, R., Gavino, M., \& Williams, D. (2015). Social Networks of Latino and Latina Entrepreneurs and Their Impact on Venture Performance. Academy of Entrepreneurship Journal, 21, 59-81.

Ponzio, M., Brichetto, G., Zaratin, P., \& Battaglia, M. A. (2015). Workers with Disability: The Case of Multiple Sclerosis. Neurological Sciences, 36, 1835-1841. https://doi.org/10.1007/s10072-015-2265-3

Reddington, T., \& Fitzsimons, J. (2013). People with Learning Disabilities and Microenterprise. Tizard Learning Disability Review, 18, 124-131.

https://doi.org/10.1108/TLDR-02-2013-0013

Renko, M., Parker Harris, S., \& Caldwell, K. (2016). Entrepreneurial Entry by People with Disabilities. International Small Business Journal, 34, 555-578. https://doi.org/10.1177/0266242615579112

Resnick, D. M. (2015). What Is Ethics in Research \& Why Is It Important? http://www.niehs.nih.gov/research/resources/bioethics/whatis

Rodríguez-Gutiérrez, M. J., Moreno, P., \& Tejada, P. (2015). Entrepreneurial Orientation and Performance of SMEs in the Services Industry. Journal of Organizational Change Management, 28, 194-212. https://doi.org/10.1108/JOCM-01-2015-0020

Rule, P., \& John, V. M. (2015). A Necessary Dialogue. International Journal of Qualitative Methods, 14. https://doi.org/10.1177/1609406915611575

Saunders, S. L., \& Nedelec, B. (2014). What Work Means to People with Work Disability: A Scoping Review. Journal of Occupational Rehabilitation, 24, 100-110. https://doi.org/10.1007/s10926-013-9436-y

Shabani Varaki, B., Floden, R. E., \& Javidi Kalatehjafarabadi, T. (2015). Para-Quantitative Methodology: Reclaiming Experimentalism in Educational Research. Open Review of Educational Research, 2, 26-41. https://doi.org/10.1080/23265507.2014.986189

Simpson, A., \& Quigley, C. F. (2016). The Qualitative Report: An Online Journal Dedicated to Qualitative Research since 1990. The Qualitative Report, 2, 376-392.

Tarilaye, N., \& Okoye, E. I. (2017). Achieving Inclusive Growth through Entrepreneurship Financing in Nigeria: Challenges and Prospects. In The 2017 International Conference on African Entrepreneurship and Innovation for Sustainable Development.

Tasavori, M., Ghauri, P. N., \& Zaefarian, R. (2016). Entering the Base of the Pyramid Market in India. International Marketing Review, 33, 555-579.

https://doi.org/10.1108/IMR-03-2014-0085

Tipu, S. A. A. (2016). Comparing the Behaviour of Opportunity and Necessity Driven Entrepreneurs. International Journal of Entrepreneurship and Small Business, 27, 84.

https://doi.org/10.1504/IJESB.2016.073359 
Van Gelderen, M., Kautonen, T., \& Fink, M. (2015). From Entrepreneurial Intentions to Actions: Self-Control and Action-Related Doubt, Fear, and Aversion. Journal of Business Venturing, 30, 655-673. https://doi.org/10.1016/j.jbusvent.2015.01.003

Walter, S. G., \& Heinrichs, S. (2015). Who Becomes an Entrepreneur? A 30-Years-Review of Individual-Level Research. Journal of Small Business and Enterprise Development, 22, 225-248. https://doi.org/10.1108/JSBED-09-2012-0106

Weber, O., \& Ahmad, A. (2014). Empowerment through Microfinance: The Relation between Loan Cycle and Level of Employment. World Development, 62, 75-87. https://doi.org/10.1016/j.worlddev.2014.05.012

Wilson, V. (2016). Research Methods, Design, Methods, Case Study...Oh My! Evidenced Based Library and Information Practice, 6, 90-91. https://doi.org/10.18438/B87W5S

Xu, B., Zheng, H., Xu, Y., \& Wang, T. (2016). Configurational Paths to Sponsor Satisfaction in Crowdfunding. Journal of Business Research, 69, 915-927.

https://doi.org/10.1016/j.jbusres.2015.06.040 